\title{
Prevalence of Allergic Rhinitis and Risk Factors in School Children
}

\author{
Müge Ayanoğlu ${ }^{1,2} \oplus$, Demet Can ${ }^{4} \oplus$, Hikmet Tekin Nacaroğlu ${ }^{4} \oplus$, ilker Günay ${ }^{1}$, Hacer Kamalı ${ }^{1 \oplus}$

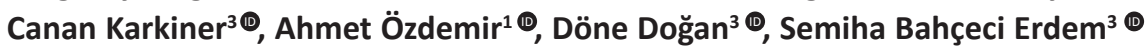

\footnotetext{
${ }^{1}$ University of Health Sciences, Izmir Dr Behçet Uz Children Research and Training Hospital, Department of Pediatrics, İzmir, Turkey

2 Aydın Adnan Menderes University, Department of Pediatrics, Division of Pediatric Neurology, Aydın, Turkey

${ }^{3}$ University of Health Sciences, Izmir Dr Behçet Uz Children Research and Training Hospital, Department of Pediatric Allergy and Immunology, Izmir, Turkey ${ }^{4}$ Istanbul Medipol University, Department of Pediatric Allergy and
Immunology, Istanbul, Turkey
}

Cite as: Ayanoğlu M, Can D, Nacaroğlu HT, et al. Prevalence of allergic rhinitis and risk factors in school children. Trends in Pediatrics 2021;2(2):67-77.

Received: 24 March 2021

Accepted: 05 May 2021

Publication date: 29 June 2021

Keywords: Allergic rhinitis in childhood, ISAAC, skin-prick test, peak nasal inspiratory flow

\section{Müge Ayanoğlu}

Aydın Adnan Menderes University, Department of Pediatrics, Division of Pediatric Neurology, Kepez Mevkii, 09001 Aydın, Turkey

ORCID: 0000-0002-0556-1435

mugeayanoglu_05@hotmail.com

D. Can 0000-0002-1258-9348

HT. Nacaroğlu 0000-0003-1333-2648

i. Günay 0000-0001-8373-9430

H. Kamalı 0000-0002-2947-6120

C. Karkiner 0000-0001-6662-8288

A. Özdemir 0000-0003-1162-0849

D. Doğan 0000-0003-0994-7359

E. Bahçeci 0000-0002-1704-0442

\begin{abstract}
Objective: To evaluate the prevalence and the risk factors of allergic rhinitis in a particular area.

Methods: The main study group consisted of all school children in Kemalpasa district aged 13-14 years. Children with current rhinitis based on responses given in ISAAC questionnaire survey were further evaluated for confirmation. Parents responded to a more detailed questionnaire about allergic diseases and risk factors. Then peak nasal inspiratory flow (PNIF) was evaluated to objectively assess nasal patency. Skin-prick test was performed for ten common allergens.

Results: The questionnaire was answered by $90.8 \%$ (1373) of children. The prevalence of physician-diagnosed AR was $11.1 \%$. Current rhinitis was found to be $31.3 \%$. Of this group, $55.0 \%$ were admitted for the parent questionnaire and tests. Precisely, 90.3\% of children accepted PNIF evaluation, and \%10.1 of them had a nasal obstruction. Skin-prick tests revealed allergy for at least 1 allergen in $16.6 \%$ of children. The present study showed that the children with maternal allergic rhinitis history had 2,18 fold, and the children with seasonal allergic rhinitis had 2,11 fold higher possibility of sensitization to an allergen. The probability of perennial allergic rhinitis was 3,1 fold higher in the children who had siblings with allergic rhinitis.

Conclusion: We included all children in a specific age group living in an area in our survey. As well as we found the prevalence of current rhinitis with the ISAAC questionnaire; we also evaluated peak nasal inspiratory flow and used skin-prick tests that yielded objective results.
\end{abstract}




\section{INTRODUCTION}

Allergic rhinitis (AR) is a global health problem with high prevalence, chronicity, and the burden that imposes on individuals and society. Its estimated worldwide prevalence is $10-25 \%$. The incidence rates of AR and asthma have increased since the 1960s in Western and middle-income countries. ${ }^{1}$ Although it is not a fatal disease, it reduces the school performance and quality of life in children. ${ }^{2}$ The social and economic costs are striking due to the effects on social life, school performance, and sleep quality. ${ }^{3}$ Additionally, its coexistence with asthma is frequently seen. ${ }^{4}$ Previous studies regarding risk factors of AR are the presence of any atopy history in the family, maternal smoking, indoor exposure to allergens, $>100 \mathrm{IU} / \mathrm{mL}$ levels of IgE before age 6 , and the presence of allergic specific IgE. ${ }^{5}$ Allergic Rhinitis is divided into two subcategories (seasonal and perennial) according to the duration of the symptoms. Mold, dust mites, and animals are the perennial triggers since they present year-round. Pollens of trees, grass, and weed species are seasonal triggers as they exist in a certain period of the year. ${ }^{6}$

The "International study of Asthma and Allergic Diseases in Childhood" (ISAAC) questionnaire survey has been designed to standardize the epidemiological studies. The first phase was designed to determine the prevalence of allergic diseases. The phase I questionnaire was translated into Turkish, and its validity and reliability were proven by previous studies. ${ }^{7-9}$ A questionnaire, which was conducted on the parents in the second part of the study, was formed to investigate the reasons for variations in prevalences in ISAAC phase I. Studies using the ISAAC method on the prevalence of allergic rhinitis have been conducted through sampling due to the difficulty of applying them on all children in a region. ${ }^{10-12}$ Hence, we aimed to identify prevalence of allergic rhinitis in a group of children at the same age and environment and define the risk factors of seasonal, and perennial allergic rhinitis.

\section{MATERIAL and METHODS}

a) Selection of samples and method of questionnaire The present study was performed in Kemalpaşa in 2012, in accordance with the ISAAC phase I studies.
Kemalpaşa is a major industrial district of İzmir, which is the third-largest city in Turkey. There are five elementary schools in the district center, and all 13-14-year-old students were given the ISAAC phase I questionnaire forms. Rhinitis symptoms were investigated based on a positive answer to the following questions: i) "ever rhinitis" was defined as a positive response to "have you ever had a problem with sneezing or a runny or blocked nose when you did not have a cold or the flu, ii) "current rhinitis" symptoms were evaluated as getting a positive answer to "in the past 12 months, have you ever had a problem with sneezing or a runny or blocked nose when you did not have a cold or the flu". Students with symptoms occurring only between March and October were classified as having "seasonal rhinitis," whereas, students with symptoms occurring throughout the year were classified as having "perennial rhinitis". ${ }^{13}$

Children with current rhinitis and their parents were invited to the Kemalpaşa Health Center in the second part of the study. Some of the children accepted the invitation and came for further investigation with their parents. Parents were given another questionnaire form regarding allergic rhinitis which was expanded with demographic questions including the socio-economic status of the family. The questions concerning allergic rhinitis were: $i)$ in the past 12 months, has your child ever taken a medication for the symptoms of allergic rhinitis, ii) in the past 12 months, has your child ever treated with immunotherapy for allergic rhinitis, iii) how do you classify your child's severity of symptoms; mild-, or moderate-severe intensity. A scale, by Boratav and Belek, was applied to the parents to evaluate their socio-economic status. Mothers and fathers categorized into three groups according to their scores concerning their levels of education: i) illiterate, or literate but did not graduate from a primary school (Level-1, 1 point), ii) graduated from a primary school (Level-2, 2 points), iii) graduated from a middle school or beyond (Level-3, 3 points). The socio-economic classification was made on the occupations of household members: i) the parents who were working in their own or someone else's business as lower- or mid-level workers were categorized on higher socio-economic status (high, 3 points), ii) the parents who were working as a white- 
collar worker, or owned a small business with bluecollar workers were categorized on middle socioeconomic status (middle, 2 points), iii) the parents who were unskilled day laborers, or unemployed were categorized on lower socio-economic status (Low, 1 point)..$^{14,15}$

\section{b) Skin Prick Test}

The skin prick test was administered to the children with current rhinitis for Dermatophagoides pteronyssinus, Dermatophagoides farinae, Alternaria alternata, cats, a grass mixture (Phleum pratense, Poapratensis, and Avena eliator), a tree mixture (Betula verrucosa, Alnus glutinosa, and Coryllus avellena), Olea europa, Blatella germanica, histamine, and negative controls. Standardized core allergen extracts and controls were provided by ALK-abello, Horsholm, Denmark. The administration of the allergen extracts is ensured by a prick test device on the volar surfaces of both forearms. The results were evaluated after 15 minutes. When the mean wheal diameter was larger than $3 \mathrm{~mm}$ compared to the negative control, the result was accepted as positive. ${ }^{16}$

\section{c) Peak nasal inspiratory flow (PNIF)}

Nasal peak flow meter is a device that determines the nasal obstruction with $80 \%$ specificity, $77 \%$ sensitivity, and $75 \%$ accuracy. ${ }^{17}$ Nasal peak flow meter (In-Check, HS Clement Clarke International) was utilized to measure the PNIF of the children with current rhinitis. The device was disinfected with $70 \%$ alcohol after each use. PNIF values obtained in our study were interpreted to the percentile values of Turkish children by age, which was previously determined by Can et al. ${ }^{18}$, and below the 50th percentile was accepted as nasal obstruction. The study design is shown in Table 1.

\section{Table 1. Stages of the present study}

1.

Defining children with Current Rhininits using ISAAC Phase One

2.

Children with current rhinitis were invited to the family physicians office with their families.

3.

Parents were given detailed family interview (ISAAC Phase Two Questionnaire and sociocultural status scale)

4. Administered to all particiants: SPTs and PNIF

\section{d) Statistical analysis}

Social Sciences Statistics Package for Windows (SPSS Inc., Chicago) 21 package program was used for statistics of the study. The Kolmogorov-Smirnov test was applied to quantitative data to detect conformity to the normal distribution, and values were stated as median and interquartile range. Mann-Whitney $U$ test and independent-sample t-test were used in the analysis of quantitative data. The chi-square test was applied to compare the categorical variables between groups, and the Fischer test was used when the chisquare test was inappropriate. Binary logistic regression was applied to assess the risk analysis. A value of $p<0.05$ was accepted as statistically significant.

\section{e) Ethical issues}

The study protocol was approved by the local ethics committee (27.09.2012/52) and followed the principles for human investigations outlined in the Second Declaration of Helsinki. Informed consent was taken from the guardians of the children. Permissions from the central and provincial directors of the Ministry of Education and town governors were obtained.

\section{RESULTS}

The total number of students in Kemalpaşa district was 1511 . The ISAAC phase I questionnaire was answered by 1373 (90.8\%) of the students. According to the ISAAC phase I questionnaire scores, the rates of ever rhinitis, current rhinitis, allergic rhinoconjonctuvitis, physician-diagnosed AR, seasonal AR, and perennial AR were $503(36.6 \%), 430(31.3 \%)$, 304 (22.1\%), 153 (11.1\%), 117 (8.5\%), 230 (16.7\%), respectively (Table 2). However, 277 (20.1\%) students, who accepted the invitation and further investigation, could be included in the second part of the study.

Table 2. Results of ISAAC phase I questionnaire of all 13-14year-old participants in Kemalpaşa district $(n=1373)$

Ever rhinitis

\section{n}

Current rhinitis 503

Allergic rhino-conjonct

430

Physician-diagnosed allergic rhinitis

304

153

Seasonal allergic rhinitis

117

230

\section{$\%$}




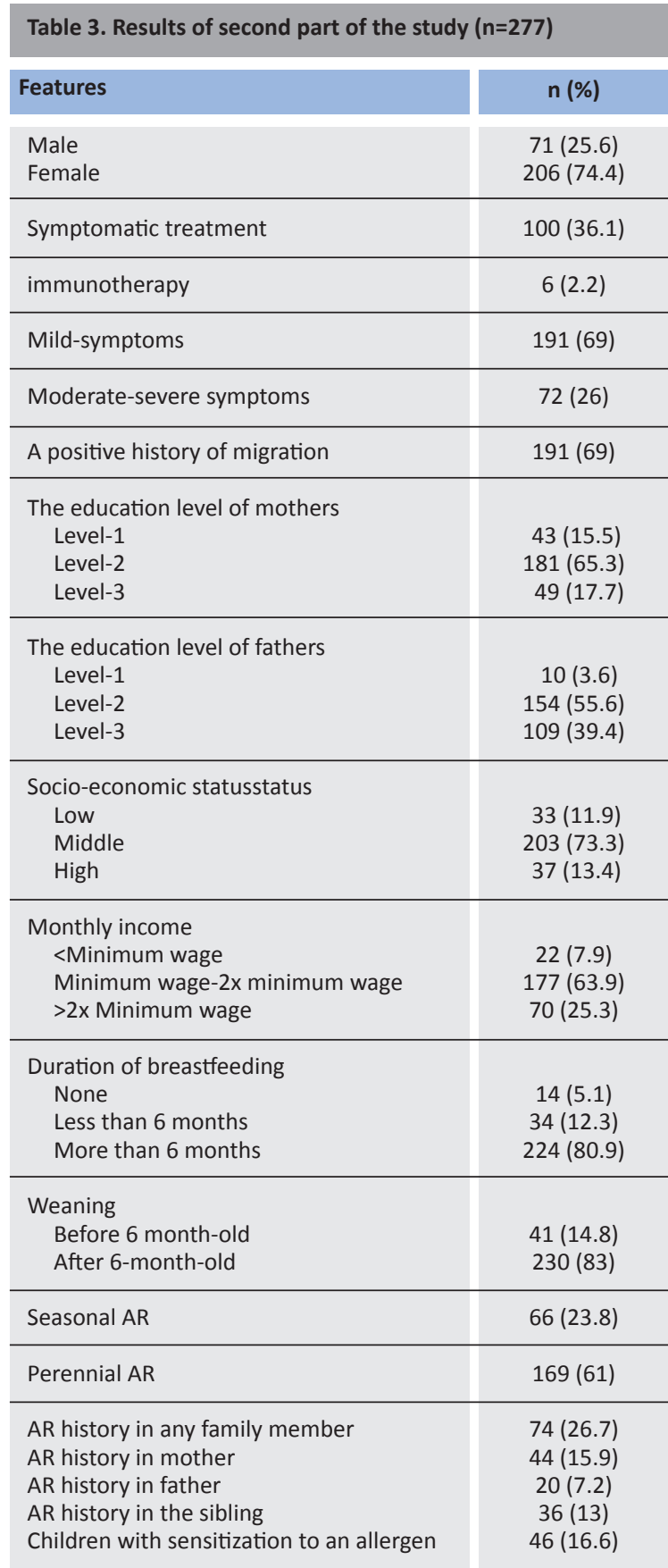

Therefore, 277 (female: 206, 74.4\%) parents answered the questionnaires regarding allergic rhinitis and socio-economic status. According to the parents' answers in the second part of the study, symptomatic treatment and immunotherapy rates were $100(36.1 \%)$ and $6(2.2 \%)$, respectively. Thirty (10.8\%) parents did not answer the question regarding the treatment history. One hundred and ninety-one (69\%) children had mild, and 72 (26\%) children had moderate-severe rhinitis symptoms. Responses of 14 (5.1\%) parents were insufficient to assess the symptom severity of their children. The distribution of respective education levels of mothers and fathers were as follows; illiterate, or literate but did not graduate from a primary school (Level-1) ( $n=43,15.5 \%$ vs $n=10,3.6 \%)$, primary school graduates (Level-2) ( $n=181,65.3 \%$ vs $n=154,55.6 \%)$, secondary, high school or university graduates (Level- 3 ) ( $n=49,11.7 \%$ vs $\mathrm{n}=109,39.4 \%)$. The most of the families were categorized in middle socio-economic status $(n=203,73.3 \%)$, the remaining were in higher $(n=37,13.4 \%)$, and lower $(n=33,11.9 \%)$ socioeconomic status. As we browse through the rates of atopy history for families; 23 (8.3\%) mothers had asthma, $44(15.9 \%)$ had AR, and 7 (2.5\%) had eczema. Eight (2.9\%) fathers had asthma, 20 (7.2\%) had AR, and 6 (2.2\%) had eczema. Eight (2.9\%) children had a sibling with asthma, $36(13 \%)$ had a sibling with $A R$, and 7 (2.5\%) had a sibling with eczema. One hundred and fifty-five (56.3\%) children had a history of exposure to passive smoking. Sixty-nine (24.9\%) children had a previous diagnosis of AR made by a physician (Table 3 ).

Peak nasal inspiratory flow evaluation was accepted by $250(90.3 \%)$ children, and results of $28(10.1 \%)$ children were compatible with severe nasal obstruction. According to the skin-prick test results, $56(16.6 \%)$ children had sensitization to at least one allergen. Household mites (Dermatophagoides pteronyssinus and Dermatophagoides farinea), grass polen and cockroach were the most frequent allergens seen. The distribution of skin-prick test results was summarized in Table 4. There were no significant differences between children with and without sensitization to an allergen in terms of age, gender, socio-economic status, duration of breastfeeding, weaning time, and the educational levels of parents. However, the presence of maternal AR history was significantly higher in patients with sensitization to an allergen $(p=0.039)$ (Table 5$)$. There were no significant differences between the children with seasonal and perennial AR in terms of demographical features. Having a sensitization to an allergen was more frequent in children with seasonal AR than in 
Table 4. The distribution of the skin-prick test results $(\mathbf{n}=\mathbf{2 7 7})$

Allergen Extracts
Dermatofoides Farinea
Dermatofoides Pteronysinus
Mold
Cat
Olea Europaea
Trees
Grass
Cockroach

\begin{tabular}{|r|r|}
\hline $\mathbf{n}$ & $\%$ \\
\hline 27 & 9.8 \\
\hline 20 & 7.2 \\
\hline 2 & 0.7 \\
5 & 1.8 \\
7 & 2.5 \\
\hline 4 & 1.4 \\
16 & 5.8 \\
12 & 4.3 \\
\hline
\end{tabular}

children with perennial AR (Table 6). The univariate logistic regression model demonstrated that the presence of seasonal AR (OR: 2.11, 95\% Cl:1.084.10) and maternal AR (OR:2.18, 95\% Cl:1.02-4.65) were the risk factors for having a sensitization to at least one allergen (Table 7). The logistic regression model showed that having a sibling with $A R$ was a risk factor for perennial AR (OR: 4.44, 95\% Cl: 1.374.36, Table 8).

Table 5. The comparison of the demographical features between children with and without sensitization to an allergen ( $n=277)$

\begin{tabular}{|c|c|c|c|}
\hline Features & $\begin{array}{l}\text { Children without sensitization to } \\
\text { an allergen }\end{array}$ & $\begin{array}{l}\text { Children with sensitization to } \\
\text { an allergen }\end{array}$ & p-value \\
\hline Age $(\text { mean } \pm S D)^{*}$ & $13.6 \pm 0.64$ & $13.43 \pm 0.54$ & 0.058 \\
\hline $\begin{array}{l}\text { Male } \mathrm{n}(\%)^{* *} \\
\text { Female } \mathrm{n}(\%)^{* *}\end{array}$ & $\begin{array}{rr}56 & (24.2) \\
175 & (75.8)\end{array}$ & $\begin{array}{l}15(32.6) \\
31(67.5)\end{array}$ & 0.235 \\
\hline A positive history of migration $\mathrm{n}(\%)^{* *}$ & $158(69.3)$ & $31(67.4)$ & 0.742 \\
\hline $\begin{array}{l}\text { The education level of mothers } n(\%)^{* *} \\
\text { Level-1 } \\
\text { Level-2 } \\
\text { Level-3 }\end{array}$ & $\begin{array}{c}41(18) \\
147(64.5) \\
40(17.5)\end{array}$ & $\begin{array}{c}2(4.4) \\
34(75.6) \\
9(20)\end{array}$ & 0.074 \\
\hline $\begin{array}{l}\text { The education level of fathers } n(\%)^{* *} \\
\text { Level-1 } \\
\text { Level-2 } \\
\text { Level-3 }\end{array}$ & $\begin{array}{c}9(3.9) \\
125(54.8) \\
94(41.2)\end{array}$ & $\begin{array}{c}1(2.2) \\
29(64.4) \\
15(33.3)\end{array}$ & 0.852 \\
\hline $\begin{array}{l}\text { Socio-economic status } \mathrm{n}(\%)^{* *} \\
\text { Low } \\
\text { Middle } \\
\text { High }\end{array}$ & $\begin{array}{l}31(13.6) \\
166(72.8) \\
31(13.6)\end{array}$ & $\begin{array}{l}2(4.4) \\
36(80.0) \\
7(15.6)\end{array}$ & 0.413 \\
\hline $\begin{array}{l}\text { Monthly income } \mathrm{n}(\%)^{* *} \\
<\text { Minimum wage } \\
\text { Minimum wage- } 2 \mathrm{x} \text { minimum wage } \\
>2 \mathrm{x} \text { Minimum wage }\end{array}$ & $\begin{array}{c}20(8.9) \\
144(64.3) \\
60(26.8)\end{array}$ & $\begin{array}{c}2(4.4) \\
33(73.3) \\
10(22.2)\end{array}$ & 0.592 \\
\hline Number of siblings (mean $\pm S D$ )* & $2.53 \pm 1.96$ & $2.15 \pm 1.21$ & 0.425 \\
\hline $\begin{array}{l}\text { Duration of breastfeeding } \mathrm{n}(\%)^{* *} \\
\text { None } \\
\text { Less than } 6 \text { months } \\
\text { More than } 6 \text { months }\end{array}$ & $\begin{array}{c}11(4.8) \\
29(12.8) \\
187(82.4)\end{array}$ & $\begin{array}{c}3(6.7) \\
5(11.1) \\
37(82.2)\end{array}$ & 0.852 \\
\hline $\begin{array}{l}\text { Weaning } \mathrm{n}(\%)^{* *} \\
\text { Before 6-month-old } \\
\text { After 6-month-old }\end{array}$ & $\begin{array}{c}34(15) \\
192(85)\end{array}$ & $\begin{array}{c}7(15.6) \\
38(84.4)\end{array}$ & 0.621 \\
\hline Seasonal AR n (\%)** & $54 / 231(23.4)$ & $18 / 231(39.1)$ & 0.026 \\
\hline Perennial AR n (\%)** & $151 / 231(65.4)$ & $18 / 231(39.1)$ & 0.001 \\
\hline AR history in any family member $n(\%)^{* *}$ & $57(24.9)$ & $17(37.8)$ & 0.089 \\
\hline AR history in mother $\mathrm{n}(\%)^{* *}$ & $32(14,0)$ & $12(26.7)$ & 0.039 \\
\hline AR history in father $\mathrm{n}(\%)^{* *}$ & $15(6.6)$ & $5(11.1)$ & 0.299 \\
\hline AR history in the sibling $\mathrm{n}(\%)^{* *}$ & $29(12.7)$ & $7(15.6)$ & 0.632 \\
\hline \multicolumn{4}{|c|}{$\begin{array}{l}\text { Mann-Whitney U test and independent-sample t-test were used in the analysis of quantitative data. The chi-square test was applied to compare the categorica } \\
\text { variables between groups, and the Fischer test was used when the chi-square test was inappropriate. } \\
\text { AR: Allergic Rhinitis, SD: Standard deviation; AR: Allergic Rhinitis } \\
{ }^{*} \text { Normally distrubuted data were given as mean } \pm S D \text { (Independent-samples } t \text { test) } \\
\text { ** The chi-square test was applied to compare the categorial variables between groups, and the Fischer test was used when the chi-square test was inappropriate }\end{array}$} \\
\hline
\end{tabular}


Table 6. The comparison of the demographical features between children with seasonal AR and perennial AR $(n=277)$

\begin{tabular}{|c|c|c|c|}
\hline & Seasonal AR & Perennial AR & p-value \\
\hline Age (mean $\pm S D)^{*}$ & $13.6 \pm 0.60$ & $13.54 \pm 0.65$ & 0.503 \\
\hline $\begin{array}{l}\text { Male } \mathrm{n}(\%)^{* *} \\
\text { Female } \mathrm{n}(\%)^{* *}\end{array}$ & $\begin{array}{l}18(27.3) \\
48(72.7)\end{array}$ & $\begin{array}{c}38(22.5) \\
131(77.5)\end{array}$ & 0.439 \\
\hline Positive history of migration $\mathrm{n}(\%)^{* *}$ & $141(69.1)$ & $50(71.4)$ & 0.932 \\
\hline $\begin{array}{l}\text { The education level of mothers } n(\%)^{* *} \\
\text { Level-1 } \\
\text { Level-2 } \\
\text { Level-3 }\end{array}$ & $\begin{array}{l}8(12.3) \\
41(63.1) \\
16(24.6)\end{array}$ & $\begin{array}{l}31(18.6) \\
109(65.3) \\
27(16.2)\end{array}$ & 0.232 \\
\hline $\begin{array}{l}\text { The education level of fathers } n(\%)^{* *} \\
\text { Level-1 } \\
\text { Level-2 } \\
\text { Level-3 }\end{array}$ & $\begin{array}{c}8(4.0) \\
113(55.9) \\
25(13.6)\end{array}$ & $\begin{aligned} 2 & (2.8) \\
41 & (57.7) \\
28 & (39.4)\end{aligned}$ & 0.231 \\
\hline $\begin{array}{l}\text { Socio-economic status of the family } n(\%) \\
\text { Low } \\
\text { Middle } \\
\text { High }\end{array}$ & $\begin{array}{l}27(13.3) \\
151(74.4) \\
25(13.6)\end{array}$ & $\begin{array}{c}7(9.9) \\
51(71.8) \\
13(13.6)\end{array}$ & 0.188 \\
\hline $\begin{array}{l}\text { Monthly income } \mathrm{n}(\%)^{* *} \\
\text { <Minimum wage } \\
\text { Minimum wage-2x minimum wage } \\
>2 \mathrm{x} \text { Minimum wage }\end{array}$ & $\begin{array}{c}16(8) \\
135(67.5) \\
49(24.5)\end{array}$ & $\begin{array}{l}8(11.3) \\
42(59.2) \\
21(29.6)\end{array}$ & 0.402 \\
\hline Number of siblings* & $2.43 \pm 1.67$ & $2.15 \pm 1.21$ & 0.425 \\
\hline $\begin{array}{l}\text { Duration of breastfeeding } \mathrm{n}(\%)^{* *} \\
\text { None } \\
\text { Lessthan } 6 \text { months } \\
\text { Morethan } 6 \text { months }\end{array}$ & $\begin{array}{c}5(7.8) \\
8(12.5) \\
51(79.7)\end{array}$ & $\begin{array}{c}8(4.8) \\
20(12) \\
139(83.2)\end{array}$ & 0.660 \\
\hline $\begin{array}{l}\text { Weaning } \mathrm{n}(\%)^{* *} \\
\text { Before } 6 \text { month-old } \\
\text { After 6-month-old }\end{array}$ & $\begin{array}{c}9(14.1) \\
55(85.9)\end{array}$ & $\begin{array}{c}23(13.9) \\
143(86.1)\end{array}$ & 0.963 \\
\hline AR history in any family member $\mathrm{n}(\%)^{* *}$ & $19(28.8)$ & $46(27.4)$ & 0.829 \\
\hline AR history in mother $\mathrm{n}(\%)^{* *}$ & $16(24.2)$ & $22(13.1)$ & 0.037 \\
\hline AR history in father $\mathrm{n}(\%)^{* *}$ & $6(9.1)$ & $12(7.1)$ & 0.615 \\
\hline AR history in the sibling $\mathrm{n}(\%)^{* *}$ & $4(6.1)$ & $28(16.7)$ & 0.034 \\
\hline $\begin{array}{l}\text { SD: Standard deviation; AR: Allergic Rhini } \\
\text { *Normally distrubuted data were given a } \\
\text { **The chi-square test was applied to com } \\
\text { test was inappropriate }\end{array}$ & $\begin{array}{l}\text { t-samples } t \\
\text { bles betweer }\end{array}$ & rtest was use & i-square \\
\hline
\end{tabular}

\section{DISCUSSION}

The major findings of the present study were: i) according to the student's answers the prevalence of current rhinitis was $31.3 \%$, physician-diagnosed AR was $11.1 \%$, allergic rhino-conjunctivitis was $22.1 \%$, ii) house dust mites (Dermatophagoides pteronyssinus and Dermatophagoides farinea), grass pollens, and cockroach were the most frequent allergens, iii) the presence of maternal AR history was significantly higher in patients with sensitization to an allergen than in patients without sensitization to an allergen, iv) the frequency of having a sensitization to an allergen was significantly higher in children with seasonal $A R$ than in children with perennial AR $v$ ) having a sibling with $A R$ was a risk factor for perennial AR.

The number of epidemiological researches on $A R$ is 


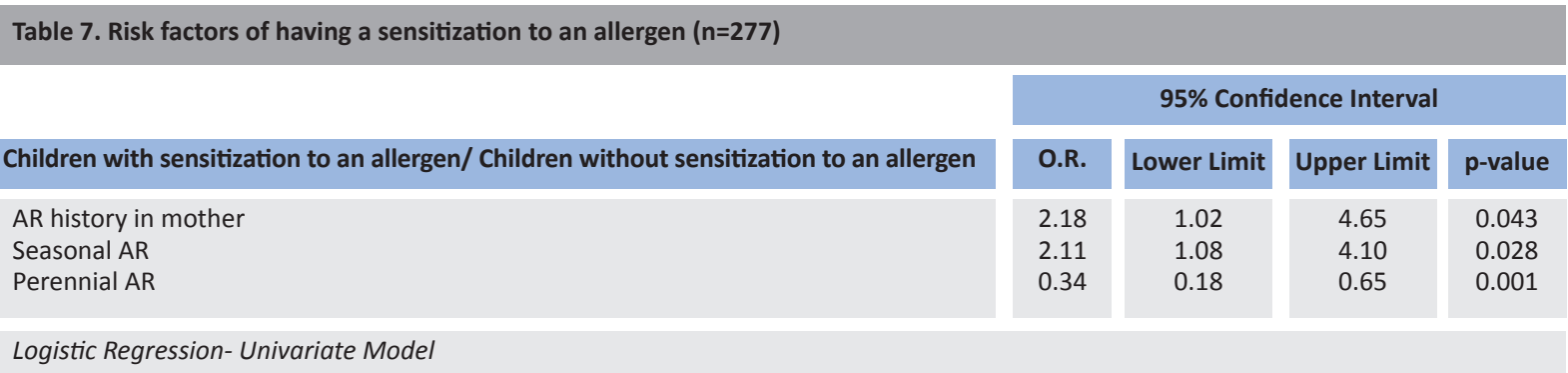

Table 8. Risk analysis of seasonal and perennial allergic rhinitis $(n=277)$

\begin{tabular}{|c|c|c|c|c|}
\hline \multirow[b]{2}{*}{ Seasonal AR/ Perennial AR } & \multicolumn{4}{|c|}{ 95\% Confidence Interval } \\
\hline & O.R. & Lower Limit & Upper Limit & p-value \\
\hline AR history in mother & 0.47 & 0.23 & 0.97 & 0.040 \\
\hline AR history in sibling & 3.10 & 1.04 & 9.22 & 0.042 \\
\hline D. farinea & 0.35 & 0.14 & 0.88 & 0.026 \\
\hline
\end{tabular}

inadequate to specify the disease prevalence and its burden. Additionally, the answers may vary based on the awareness of the population concerning allergic diseases especially in questionnaire-based studies. ${ }^{19}$ In addition, the prevalence of allergic rhinitis varies according to the age group of the children. In the ISAAC Phase I Study, the prevalence of AR among 13-14-year-old children, was reported with a wide range between $1.4 \%$ and $39.7 \% .{ }^{20}$ According to an ISAAC phase III study results, the prevalence of rhinoconjunctivitis was $8.5 \%$ among 6-7-year-old children. ${ }^{21}$ In a metaanalysis by Kalmarzi from Iran, the prevalence of AR was $18 \%$ in children, and $25 \%$ in adolescents. ${ }^{22}$ In an ISAAC-based questionnaire study from Budapest including 3836 6-12-year-old children, it was reported that the prevalences of current rhinitis, physician-diagnosed AR, and current allergic rhinoconjunctivitis were $29.3 \%, 9.7 \%$, and $16.2 \%$, respectively. ${ }^{23}$ In the current study, we reported the prevalence of current rhinitis, physician-diagnosed $A R$, and allergic rhino-conjunctivitis as $31.3 \%$, $11.1 \%$, and $22.1 \%$, respectively.

Several allergic rhinitis prevalence studies using the ISAAC questionnaire were made in Turkey. Kuyucu et al. ${ }^{24}$ reported that the prevalence rates of ever rhinitis, current rhinitis, and ever hay fever were
$36.3 \%, 30.6 \%$, and $8.3 \%$, respectively among 9-11year-old children in 2006 . Civelek et al. ${ }^{13}$ reported the prevalence of rhino-conjunctivitis as $23.5 \%$ in 2010. Tamay et al. ${ }^{25}$ reported the rate of current rhinitis as $29.2 \%$ by using ISAAC questionnaire among 6- to 7-year-old children in 2014. In a study that included 396 preschool children from Mersin, Turkey, the prevalence of ever rhinitis, current rhinitis, and physician-diagnosed allergic rhinitis were $41.7 \%, 38.6 \%$, and $13.4 \%$, respectively. Demir et al. $^{27}$ reported that the prevalence of rhinitis among children aged $5-18$ years rises from $4.6 \%$ to $13.6 \%$ in the Agean region of Turkey. Kemalpaşa is in Turkey's Aegean region. Studies conducted in the same region show that the prevalence of rhinitis is increasing.

As allergens, grass pollens and house dust mites has been frequently reported as etiologic agents in AR among adults and children. Şahin et al. ${ }^{28}$ evaluated the skin prick test results in 1200 adults and children who were diagnosed with AR. It was found that house dust mites were the most frequent allergens. Kuyucu et al. ${ }^{24}$ reported a higher sensitization rates caused by grass pollens, mites, and cockroaches from Turkey. Özkars et al. ${ }^{29}$ retrospectively evaluated aeroallergen sensitivity in children, aged between 1-16 years in the Province of Kahramanmaraş. It was 
found that grass pollens and house dust mites were the most frequent allergens. In the current study, house dust mites, grass pollens and, cockroaches were the most frequent allergens which were compatible with the previous reports.

A strong correlation was found between allergic diseases and atopy in some researches. ${ }^{30,31}$ However, atopy may not be determined in all allergic patients. This situation may be related to subclinical sensitization..$^{32}$ In the present study, $16.6 \%$ of the children were allergic to at least one allergen. Performing the skin-prick tests with more allergens might ensure the determination of higher rates of atopy.

Numerous risk factors have been defined for AR and atopy in children. The presence of a family history of allergic diseases, male gender, birth during the pollen season, early-life antibiotic use, maternal smoking, exposure to indoor allergens, and serum IgE levels higher than $100 \mathrm{IU} / \mathrm{mL}$ before age 6 were considered as risk factors for $A R^{.5,32,33}$ Wang et al. ${ }^{34}$ investigated the relationship between maternal $A R$ and the allergic diseases of the children. They found that the rate of allergic diseases in children was significantly higher in the presence of coexistence of maternal AR and asthma than in the presence of maternal AR only. Kuyucu et al. ${ }^{24}$ suggested that family atopy, heating with gas stove and the presence of dampness/molds at home during the first year of life were the risk factors for current AR. Batlles-Garrido et al. proposed that atopy, cat contacts at home during the first year of life, prior diagnosis of asthma, nocturnal cough in the absence of cold, the presence of maternal or paternal AR history, wheezing at any time, and nursery school attendance were the risk factors for AR. ${ }^{35}$ Several studies have emphasized the existence of phenotype-specific genes for atopy. Additionally, it is known that the impact of the maternal phenotype is stronger than the paternal phenotype. ${ }^{36}$ Edenharter et al. ${ }^{37}$ showed that higher levels of cord blood IgE levels may have a role in the prediction of early sensitization but not for airway or skin symptoms. According to some researchers, the decline in the exposure to infections during the first year of life is considered an immunologic risk factor for atopy. The postulated mechanism is the fact that some infections induce a systemic and nonspecific switch to TH1 activities which may lead to inhibition of the development of atopy during childhood. ${ }^{38}$ The present study showed that seasonal $A R$ and the presence of maternal $A R$ history were the risk factors for atopy.

Only a few studies have been performed regarding differences between seasonal and perennial AR in terms of the presence of atopy and family history of allergic diseases. Sibbald et al. ${ }^{39}$ performed a questionnaire-based study to evaluate the symptoms, atopic state, and medical history of people with seasonal and perennial AR. The results revealed that 113 of subjects were without rhinitis, 51 had seasonal symptoms alone, 128 had perennial symptoms alone, 131 had perennial symptoms with seasonal exacerbations. Atopy rates, history of eczema, and the presence of a family history of allergic disease were significantly higher in the seasonal AR group. In a study by Mısırlığlu et al. ${ }^{40}$, no significant differences were found between seasonal and perennial AR, in terms of family history of atopy. In the present study, the rates of AR history in mothers were significantly higher in the seasonal AR group than in the perennial AR group. Additionally, logistic regression analysis showed that AR history in a sibling was a risk factor for perennial AR. This condition can be explained by genetic susceptibility. Additionally, living in the same environment may have given rise to exposure to similar allergens and microorganisms.

Fuller et al. ${ }^{41}$ performed a study to evaluate the nasal patency with PNIF and nasal obstruction symptom evaluation (NOSE) scale to assess the outcomes of functional septorhinoplasty. Although they found a weak correlation between PNIF results and NOSE scores, PNIF demonstrated the amelioration of nasal patency after rhinoplasty. Prescott et al. ${ }^{42}$ suggested that PNIF values increased with height and weight in childhood. Since the maximal nasal inspiratory effort should be made during the PNIF assessment, and the degree of cooperation of the child is important.In the present study, only $10.1 \%$ of the children in the second part of the study, PNIF results were compatible with nasal obstruction. These results may be related to the difficulty of obtaining maximum cooperation 
while performing PNIF assessment in large groups. The limitation of the questionnaire-based determining the participants in the second part of the study might also have contributed to the inconsistency of the PNIF results.

Our study has several limitations. Maybe, some children might have erroneously selected the "yes" option of the question "have you experienced rhinorrhea, nasal obstruction, or sneezing when you have not had a cold, in the past 12 months" as a handicap of the questionnaire-based study. In the current study, detection of higher rates of children without sensitization to an allergen can be explained partly by this situation. However, this limitation was tried to be corrected with applying family questionnaires. Secondly, all of the children who were categorized as patients with current rhinitis according to the ISAAC phase I questionnaire could not be included in the study group, since only $55 \%$ of them applied to the physician's office.

\section{CONCLUSION}

In conclusion, including all children of the same age and the same environment is a valuable epidemiological aspect of the present study. Applying the family questionnaires could have decreased the false-positive cases with current rhinitis. Seasonal AR and the presence of maternal atopy history are the risk factors for having a sensitization to at least one allergen. Having a sibling with AR is a risk factor for perennial AR.

Ethics Committee Approval: SB. Approval was obtained from Behçet Uz Pediatric Diseases and Surgery Training and Research Hospital NonPharmaceutical Clinical Research Ethics Committee (29.09.2012 / 52).

Conflict of Interest: The authors declared no potential conflicts of interest with respect to the research, authorship, and/or publication of this article.

Funding: The authors received no financial support for the research, authorship, and/or publication of this article.

Informed Consent: Parents of the patient provided informed consent to publish the report.

\section{REFERENCES}

1. Goronfolah L. Aeroallergens, atopy and allergic rhinitis in the Middle East. Eur Ann Allergy Clin Immunol. 2016;48:5-21.

2. Price $D$, Scadding $G$, Ryan D, et al. The hidden burden of adult allergic rhinitis: UK healthcare resource utilisation survey. Clin Transl Allergy. 2015;5:39. https://doi.org/10.1186/s13601-015-0083-6

3. Pawankar R. Allergic diseases and asthma: a global public health concern and a call to action. World Allergy Organ J. 2014;7:12.

https://doi.org/10.1186/1939-4551-7-12

4. Casale TB, Dykewicz MS. Clinical implications of the allergic rhinitis-asthma link. Am J Med Sci. 2004;327:127-38. https://doi.org/10.1097/00000441-200403000-00004

5. Matheson MC, Dharmage SC, Abramson MJ, et al. Early-life risk factors and incidence of rhinitis: results from the European Community Respiratory Health Study--an international population-based cohort study. J Allergy Clin Immunol. 2011;128:816-23.e5. https://doi.org/10.1016/j.jaci.2011.05.039

6. Siracusa A, Desrosiers M, Marabini A. Epidemiology of occupational rhinitis: prevalence, aetiology and determinants. Clin Exp Allergy. 2000;30:1519-34. https://doi.org/10.1046/j.1365-2222.2000.00946.x

7. Akçay A, Tamay Z, İnan M, et al. Denizli'deki $13-14$ yaş okul çocuklarında alerjik hastalık belirtilerinin yaygınlığı. Türk Pediatri Arşivi 2006:81-6.

8. Asher MI, Weiland SK. The International Study of Asthma and Allergies in Childhood (ISAAC). ISAAC Steering Committee. Clin Exp Allergy. 1998 Nov;28 Suppl 5:52-66; discussion 90-1. https://doi.org/10.1046/j.1365-2222.1998.028s5052.x

9. Kendirli GS, Altintaş DU, Alparslan N, et al. Prevalence of childhood allergic diseases in Adana, Southern Turkey. Eur J Epidemiol. 1998;14:347-50. https://doi.org/10.1023/A:1007455428598

10. Karaman O, Turgut CS, Uzuner N, et al. The determination of asthma, rhinitis, eczema, and atopy prevalence in 9to 11-year-old children in the city of Izmir. Allergy Asthma Proc. 2006;27:319-24. https://doi.org/10.2500/aap.2006.27.2877

11. Faniran AO, Peat JK, Woolcock AJ. Prevalence of atopy, asthma symptoms and diagnosis, and the management of asthma: comparison of an affluent and a nonaffluent country. Thorax. 1999;54:606-10. https://doi.org/10.1136/thx.54.7.606

12. Weiland SK, von Mutius E, Hirsch T, et al. Prevalence of respiratory and atopic disorders among children in the East and West of Germany five years after unification. Eur Respir J. 1999;14:862-70. https://doi.org/10.1034/j.1399-3003.1999.14d23.x

13. Civelek E, Cakir B, Boz AB, et al. Extent and burden of allergic diseases in elementary schoolchildren: a national multicenter study. J Investig Allergol Clin Immunol. 2010;20:280-8. 
14. İstanbul ve Anadolu'dan Sınıf Profilleri, Boratav K. İstanbul, İmge Kitabevi Yayınları, 2004;23-27.

15. Sınıf Sağlık Eşitsizlik. Belek i. İstanbul, Sorun Yayınları. 1998;77-99.

16. Weiland SK, Björkstén B, Brunekreef B, et al. International Study of Asthma and Allergies in Childhood Phase II Study Group. Phase II of the International Study of Asthma and Allergies in Childhood (ISAAC II): rationale and methods. Eur Respir J. 2004;24:406-12. https://doi.org/10.1183/09031936.04.00090303

17. Bermüller $\mathrm{C}$, Kirsche $\mathrm{H}$, Rettinger $\mathrm{G}$, Riechelmann $\mathrm{H}$. Diagnostic accuracy of peak nasal inspiratory flow and rhinomanometry in functional rhinosurgery. Laryngoscope. 2008;118:605-10. https://doi.org/10.1097/MLG.0b013e318161e56b

18. Can D, Gülen F, Tanaç R, Demir E, Yenigün A. Value of peak nasal inspiratory flow in Aegean school children. Asthma Allergy Immunol. 2011;9:138-43.

19. Asher MI, Keil U, Anderson HR, et al. International Study of Asthma and Allergies in Childhood (ISAAC): rationale and methods. Eur Respir J. 1995;8:483-91. https://doi.org/10.1183/09031936.95.08030483

20. Asher $M$, Stewart W. World Wide variations in the prevalence asthma symptoms: The International Study of Asthma and Allergies in Childhood (ISAAC). Eur Respir J. 1998;12:315-35. https://doi.org/10.1183/09031936.98.12020315

21. Mallol J, Crane J, von Mutius E, et al; ISAAC Phase Three Study Group. The International Study of Asthma and Allergies in Childhood (ISAAC) Phase Three: a global synthesis. Allergol Immunopathol (Madr). 2013;41:73-85.

https://doi.org/10.1016/j.aller.2012.03.001

22. Kalmarzi RN, Ataee $P$, Fathollahpour $A$, et al. The prevalence of allergic rhinitis among Iranian children: $A$ systematic review and meta-analysis. Endocr Metab Immune Disord Drug Targets. 2020;20:189-97. https://doi.org/10.2174/1871530319666190515100735

23. Sultész $M$, Horváth $A$, Molnár $D$, et al. Prevalence of allergic rhinitis, related comorbidities and risk factors in schoolchildren. Allergy Asthma Clin Immunol. 2020;16:98.

https://doi.org/10.1186/s13223-020-00495-1

24. Kuyucu S, Saraçlar Y, Tuncer A, et al. Epidemiologic characteristics of rhinitis in Turkish children: the International Study of Asthma and Allergies in Childhood (ISAAC) phase 2. Pediatr Allergy Immunol. 2006;17:269-77. https://doi.org/10.1111/j.1399-3038.2006.00407.x

25. Tamay Z, Akçay A, Ergin A, Güler N. Prevalence of allergic rhinitis and risk factors in 6- to 7-year old children in İstanbul, Turkey. Turk J Pediatr. 2014;56:31-40. https://doi.org/10.2332/allergolint.13-OA-0661

26. Bolat E, Arikoglu T, Sungur MA, Batmaz SB, Kuyucu S. Prevalence and risk factors for wheezing and allergic diseases in preschool children: A perspective from the Mediterranean coast of Turkey. Allergol Immunopathol
(Madr). 2017;45:362-8.

https://doi.org/10.1016/j.aller.2017.01.002

27. Demir $E$, Tanaç $R$, Can $D$, et al. Is there an increase in the prevalence of allergic diseases among schoolchildren from the Aegean region of Turkey? Allergy Asthma Proc. 2005;26:410-4.

28. Şahin E, Sizdar D, Dinç ME. Evaluation of skin prick test results in patients with respiratory tract allergy symptoms in the Kadıköy district of İstanbul. Electronic Journal of Otolaryngology- head and neck surgery. 2017;162:58-63.

29. Özkars MY, Kırık S. Determination of aeroallergen prevalence in children aged 1-16 years in the provincial center of Kahramanmaraş. Ann Med Res. 2020;27:903-6. https://doi.org/10.5455/annalsmedres.2019.08.488

30. Celedón JC, Soto-Quiros ME, Hanson LA, Weiss ST. The relationship among markers of allergy, asthma, allergic rhinitis, and eczema in Costa Rica. Pediatr Allergy Immunol. 2002;13:91-7. https://doi.org/10.1034/j.1399-3038.2002.00083.x

31. Arshad SH, Tariq SM, Matthews S, Hakim E. Sensitization to common allergens and its association with allergic disorders at age 4 years: a whole population birth cohort study. Pediatrics. 2001;108:E33. https://doi.org/10.1542/peds.108.2.e33

32. Torres-Borrego J, Molina-Terán AB, Montes-Mendoza C. Prevalence and associated factors of allergic rhinitis and atopic dermatitis in children. Allergol Immunopathol (Madr). 2008;36:90-100. https://doi.org/10.1157/13120394

33. Saulyte J, Regueira C, Montes-Martínez A, Khudyakov $\mathrm{P}$, Takkouche B. Active or passive exposure to tobacco smoking and allergic rhinitis, allergic dermatitis, and food allergy in adults and children: a systematic review and meta-analysis. PLoS Med. 2014;11:e1001611. https://doi.org/10.1371/journal.pmed.1001611

34. Wang QP, Wu KM, Li ZQ, et al. Association between maternal allergic rhinitis and asthma on the prevalence of atopic disease in offspring. Int Arch Allergy Immunol. 2012;157:379-86. https://doi.org/10.1159/000328789

35. Batlles-Garrido J, Torres-Borrego J, Rubí-Ruiz T, et al. Prevalence and factors linked to allergic rhinitis in 10 and 11-year-old children in Almería. Isaac Phase II, Spain. Allergol Immunopathol (Madr). 2010;38:13541. https://doi.org/10.1016/j.aller.2009.09.005

36. Wahn U, von Mutius E. Childhood risk factors for atopy and the importance of early intervention. J Allergy Clin Immunol. 2001;107:567-74. https://doi.org/10.1067/mai.2001.112943

37. Edenharter G, Bergmann RL, Bergmann KE et al. Cord blood IgE as risk factor and predictor for atopic diseases. Clin Exp Allergy. 1998;28:671-8. https://doi.org/10.1046/j.1365-2222.1998.00241.x

38. Matricardi PM, Rosmini F, Ferrigno L, et al. Crosssectional retrospective study of prevalence of atopy among Italian military students with antibodies against 
hepatitis A virus. BMJ. 1997;3014:999-1003.

https://doi.org/10.1136/bmj.314.7086.999

39. Sibbald B, Rink E. Epidemiology of seasonal and perennial rhinitis: clinical presentation and medical history. Thorax. 1991;46:895-901.

https://doi.org/10.1136/thx.46.12.895

40. Mısırlığlu ED, Cengizliler R. Perennial ve mevsimsel allerjik rinitli çocukların değerlendirilmesi. Astım Allerji İmmunoloji. 2006;1:11-6.
41. Fuller JC, Bernstein CH, Levesque PA, Lindsay RW. Peak Nasal inspiratory flow as an objective measure of nasal obstruction and functional septorhinoplasty outcomes. JAMA Facial Plast Surg. 2018;20:175-6. https://doi.org/10.1001/jamafacial.2017.1775

42. Prescott CA, Prescott KE. Peak nasal inspiratory flow measurement: an investigation in children. Int J Pediatr Otorhinolaryngol. 1995;32:137-41.

https://doi.org/10.1016/0165-5876(94)01125-H 